\title{
The effect of musa acuminata stem in increasing macrophage and neovascular cells of healing process
}

\author{
Maharani Laillyza Apriasari*, Dewi Puspitasari**, A.Retno Pudji Rahayu***, Diah \\ Savitri Ernawati**** \\ *Departement of Oral Medicine, Faculty of Dentistry, Lambung Mangkurat University \\ **Departement of Dental Biomaterial, Faculty of Dentistry, Lambung Mangkurat University \\ ***Departement of Oral Pathology, Faculty of Dentistry, Airlangga University \\ ****Departement of Oral Medicine, Faculty of Dentistry, Airlangga University
}

\begin{abstract}
Introduction: Musa acuminata stem has both of imunostimulatory and imunosuppressant effects that are influenced by their concentrations. The study aimed to analyze the effect of Mauli banana stem extract (EMBS) to increase the number of macrophage and neovascular cells in traumatic ulcer healing. Methods: Rattus norvegicus of male Wistar strain were used as model of traumatic ulcer. The left buccal mucous was biopsied, then used the histopathology method to find the number of macrophage and neovascular cells. Results: EMBS gel was effected when administered at a concentration of 37.5\% because it significantly increased the number of macrophage and neovascular cells in traumatic ulcer healing on the $3^{\text {rd }}$ day to $5^{\text {th }}$ days. Conclusion: It can be concluded that EMBS within concentration of $37.5 \%$ can accelerate ulcer healing through the increasing number of macrophage and neovascular cells.
\end{abstract}

Keywords: Condensed tannin, macrophage, Musa acuminata, neovascular, Terpenoid saponin

p-ISSN: 1979-0201; e-ISSN: 2549-6212; Available from: http://jurnal.unpad.ac.id/pjd/article/view/18324

DOI: http://dx.doi.org/10.24198/pid.vol30no2.18324

Submission: November 14, 2017; Accepted: May 22, 2018; Published online: July 31, 2018

\section{INTRODUCTION}

Ulceration of the oral cavity is one of the most common disorders in the oral cavity. This disorder is characterized by the existence of lesions such as ulcers which lose their epithelial layers exceeding the basal membranes. ${ }^{1-3}$ Ulceration in the oral cavity becomes the main reason for patients to consult a dentist. The ulceration may be recurrent, rare occurred, or being permanent ulcerations. ${ }^{4}$
Ulceration in the oral cavity will interfere with the process of mastication, resulting in the disorders of nutrient intake. The therapy of ulceration in the oral cavity is essentially symptomatic to reduce inflammation, pain, and accelerate wound healing. ${ }^{5}$

Previous research indicates that gel extract of mauli banana stem (EMBS) can accelerate and increase epithelium thickness of the buccal mucosal wound healing in mice. ${ }^{6-8}$ EMBS has bioactive materials of mauli banana consisted of $67.59 \%$

Corresponding author: Maharani Laillyza Apriasari, Dentistry Faculty of Lambung Mangkurat University Jl Veteran 128 B, Banjarmasin, Indonesia. Phone: +62 812-2153-445 Email: maharaniroxy@gmail.com. 
of tannin, $14.49 \%$ of saponin, $0.34 \%$ of alkaloids, $0.44 \%$ of ascorbic acid, $0.25 \%$ of flavonoids, and $0.006 \%$ of lycopene. ${ }^{6}$ Condensed tannins can induce tyrosine phosphorylation of insulin receptor on the cell surface of 3T3-L1 adipocytes in vitro, so it can activate phosphatidylinositol 3-kinase pathway (PI3K), which plays a role in cell proliferation..$^{9,10}$ Terpenoid saponins will be captured by the $G$ protein receptor on macrophages, then through a process that produces a protein kinase $C$, it activates NFkB, thereby increasing the activity and number of macrophages. ${ }^{11}$

Condensed tannins and terpenoid saponins are immunomodulators that can increase the activity and the number of macrophages..$^{9-11}$ Previous research has also proven that the gel extract of mauli banana stem can increase the amount of HIF-1a, Hsp90a, and VEGF. ${ }^{8}$ Based on these facts, the study aims to analyze the effects of the gel extract of mauli banana stem to increase the number of macrophages and neovasculars on mucosal healing in traumatic ulcers.

\section{METHODS}

This experiment was a true experimental research. The experimental units were 40 rats of Rattus norvegicus of male Wistar strain. There were the traumatic ulcer models. The biopsy was taken from the ulcer in the left buccal mucous. The criteria of rats were healthy, weighed 250300 grams, and aged 2-3 months. Ethical approval was obtained at the Faculty of Dentistry, Airlangga University No 56/ KKEPK.FKG/ VI/ 2015.

Mauli banana plant was taken after producing banana fruit. The maceration method was used, followed the ethanol-free examination. The gel compositions of ethanol extract of Mauli banana stems were consisted of 3 levels i.e of $25 \%$, $37.5 \%$, and $50 \%$. The extracts were mixed with $15 \%$ HPMC, 1\% Tween 80, 8\% Propylene glycol, 5 drops of peppermint oil and distilled water until reaching concentration of $100 \%$. Materials to make the preparation and staining of histopathology were $10 \%$ BNF, alcohol, xylol, paraffin, and Haematoxylin Eosin (HE) staining.

The experiment used 40 rats, divided into 4 groups of treatment i.e, the rats administrated gel only as a negative control group $(\mathrm{K})$, rats administrated with $25 \%$ of EMBS (P1), rats admin- istrated with $37,5 \%$ of EMBS (P2), and rats administrated with $50 \%$ of EMBS (P3). Each group was consisted 10 rats. The EMBS was applied topically every 6-8 hours per day.

The treatment of experimental rats was started by giving inhaled ether anesthesia, then the left buccal mucous was injured with biopsy punch with a diameter of $6 \mathrm{~mm}$ and a depth of $1 \mathrm{~mm}$, and then it was taken with a scalpel. The left buccal mucous of the rats was biopsied on the $3^{\text {rd }}$ and $5^{\text {th }}$ day after being decapitated. The tissue

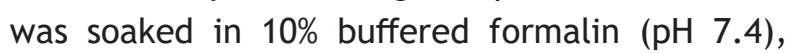
and then it was made into preparations. The next phase were done histophatology tests by using Haematoxylin Eosin (HE) staining technique to see the number of macrophage and neovascular cells. The number of macrophage and neovascular cells were calculated in three different field locations using a light microscope (Olympus, United States) under 400x magnification and subsequently averaged.

\section{RESULTS}

The results of statistical analysis using ANOVA and Post Hoc LSD examinations indicated that there was a significant difference $(p<0.05)$ in the number of macrophages based on the time of EMBS gel administration in all groups, except in the group of rats administration with EMBS gel at a concentration of $0 \%$ (negative control) on the $3^{\text {rd }}$ day compared to the $5^{\text {th }}$ day $(p=0,12)$. In the treatment groups of EMBS gel of $25 \%(p=0.006)$, EMBS gel of $37.5 \%(p=0.003)$, and EMBS gel $50 \%$ concentration $(p=0.002)$. In this study, there were increased numbers of macrophages on the $3^{\text {rd }}$ day compared to the $5^{\text {th }}$ day in all groups of EMBS gel. The highest increasing number of macrophages occured in the EMBS gel of $37.5 \%$ concentration, i.e. from 10 to 13 cells (Table 1 ).

Based on time variable of EMBS gel application, on the $3^{\text {rd }}$ day there was a significant difference between the number of macrophages of EMBS gel of $0 \%$ concentration (negative control) and all treatments, except for the EMBS gel of $25 \%$ concentration. On the $3^{\text {rd }}$ day, there was a significant difference between the number of macrophages of EMBS gel of $25 \%$ concentration and concentrations of $37.5 \%$ and $50 \%$. On the $3^{\text {rd }}$ day there was a significant difference between 
Table 1. The number of macrophage cells in traumatic ulcer healing on $3^{\text {rd }}$ until $5^{\text {th }}$ days

\begin{tabular}{|c|c|c|c|}
\hline \multirow{2}{*}{ Group } & \multicolumn{2}{|c|}{ Time } & \multirow{2}{*}{ P } \\
\hline & 3 days & 5 days & \\
\hline $0 \%$ EMBS & $5.0 \pm 1.22(3-6)$ & $6.4 \pm 1.14(5-8)$ & 0.12 \\
\hline $25 \%$ EMBS & $5.8 \pm 0.84(5-7)$ & $8.4 \pm 0.89(7-9)$ & $0.006^{*}$ \\
\hline $37.5 \%$ EMBS & $9.6 \pm 1.52(8-11)$ & $12.4 \pm 1.14(11-14)$ & $0.003^{*}$ \\
\hline $50 \%$ EMBS & $9.0 \pm 1.58(7-11)$ & $12.0 \pm 2.24(9-15)$ & $0.002^{*}$ \\
\hline$p$ & $0.000^{*}$ & $0.000^{*}$ & $0.000^{*}$ \\
\hline
\end{tabular}

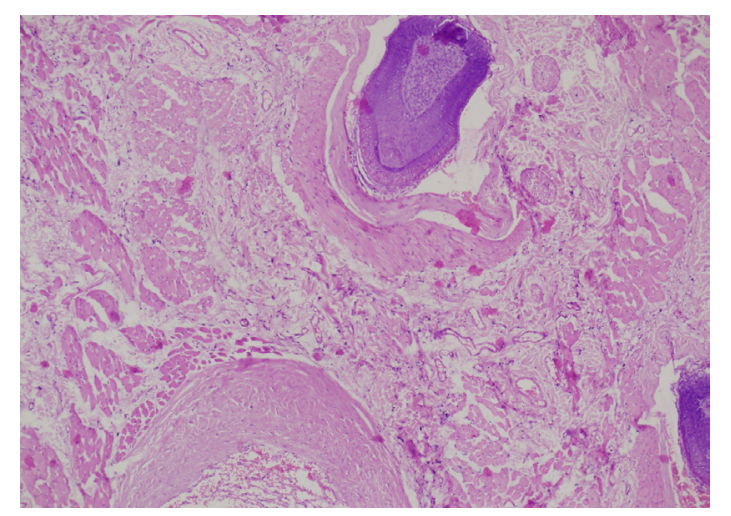

Figure 1. The results of histopathology test showed the indicate of macrophage and neovascular cells on the $3^{\text {th }}$ days

the number of macrophages of EMBS gel of $50 \%$ concentration and the EMBS gel of $37.5 \%$ concentration (Fig.1).

Based on time variable of EMBS gel application, on the $5^{\text {th }}$ day, there was a significant difference on the number of macrophages between EMBS gel of $0 \%$ concentration (Negative control) and EMBS gel of $25 \%, 37.5 \%$ and $50 \%$ concentrations. On the $5^{\text {th }}$ day, there was a significant difference on the number of macrophages between EMBS gel of $25 \%$ and EMBS gel of $0 \%$ concentration (Negative control), also with EMBS gel of $37.5 \%$ and $50 \%$ concentrations. On the $5^{\text {th }}$ day, there was a significant difference on the number of macrophages between EMBS gel of $37.5 \%$ concentration and all treatments, except with EMBS gel of $50 \%$ concentration. On the $5^{\text {th }}$ day, there was a significant difference on the number of macrophages between EMBS gel of $50 \%$ and all treatments except with EMBS gel of $37.5 \%$ concentration (Fig.2).

The results of statistical analysis using ANOVA and Post Hoc LSD examinations indicated that there was a significant difference $(p<0.05)$ on the number of neovasculars based on time variable
Table 2. The number of neovascular cells in traumatic ulcer healing on $3^{\text {rd }}$ until $5^{\text {th }}$ days

\begin{tabular}{llll}
\hline \multirow{2}{*}{ Group } & \multicolumn{2}{c}{ Time } & \multirow{2}{c}{$\mathbf{p}$} \\
\cline { 2 - 3 } & \multicolumn{1}{c}{3 days } & \multicolumn{1}{c}{5 days } & \\
\hline $0 \%$ EMBS & $4.60 \pm 1.52(3-7)$ & $6.60 \pm 2.97(3-11)$ & 0.216 \\
$25 \%$ EMBS & $7.00 \pm 1.87(5-9)$ & $11.25 \pm 0.96(10-12)$ & $0.005^{*}$ \\
$37.5 \%$ EMBS & $10.60 \pm 2.07(9-14)$ & $17.60 \pm 5.03(12-25)$ & $0.021^{*}$ \\
$50 \%$ EMBS & $6.20 \pm 1.30(5-8)$ & $9.20 \pm 2.28(7-13)$ & $0.034^{*}$ \\
\hline $\mathbf{p}$ & $0.000^{*}$ & $0.001^{*}$ & $0.000^{*}$ \\
\hline
\end{tabular}

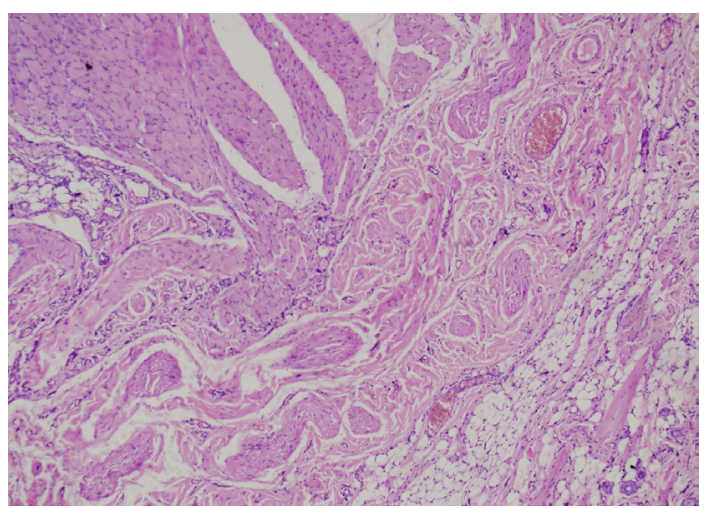

Figure 2. The results of histophatology test showed the indicate of macrophage and neovascular cells on the $5^{\text {th }}$ days

of EBPM gel application in all groups, except in the group of EMBS gel of $0 \%$ concentration (negative control) on the $3^{\text {rd }}$ day compared to the $5^{\text {th }}$ day. In the treatment group of EMBS gel of $25 \%$ concentratio $(p=0.005), 37.5 \%$ concentration $(p=0.021)$, and $50 \%$ concentration $(p=0.034)$. In this study, there was an increasing number of neovasculars on the $3^{\text {rd }}$ day compared to the $5^{\text {th }}$ day in all groups of EMBS gel. The most significant increasing number of neovasculars occurred in the EMBS gel of $37.5 \%$ concentration which was from 12 to 19 cells (Table 2 ).

Based on time variable of EMBS gel application, on the $3^{\text {rd }}$ day there was a significant difference between the number of neovasculars of EMBS gel of $0 \%$ concentration (negative control) and all treatments, except for the EMBS gel of $25 \%$ and $50 \%$ concentrations. On the 3rd day, there was a significant difference between the number of neovasculars of EMBS gel of $25 \%$ and $37.5 \%$ concentrations. On the $3^{\text {rd }}$ day, there was a significant difference between the number of neovasculars of EMBS gel of $50 \%$ concentration and of $37.5 \%$ concentration (Fig. 1 ). 
Based on time variable of EMBS gel application, on the $5^{\text {th }}$ day there was a significant difference between the number of neovasculars of EMBS gel of $0 \%$ concentration (negative control) and EMBS gel of $25 \%$ and $37.5 \%$ concentrations. On the $5^{\text {th }}$ day there was a significant difference between the number of neovasculars of EMBS gel of $25 \%$ concentration and of $0 \%$ concentration (negative control) and of $37.5 \%$ concentration. On the $5^{\text {th }}$ day, there was a significant difference between the number of neovasculars of EMBS gel of $37.5 \%$ concentration and all treatments. On the $5^{\text {th }}$ day, there was a significant difference between the number of neovasculars of EMBS gel of $50 \%$ and $37.5 \%$ concentrations (Fig 2 ).

\section{DISCUSSION}

Condensed tannins may bind in the a-subunit of the insulin receptor in the cell membrane in vitro and may make kinase tyrosine residues in B-subunit undergo autophosphorylation. The autophosphorylation from tyrosine kinase receptors can bind with PI3K and activate it. Active PI3K can catalyze the PIP3 phosphorylation, then the PIP3 recruit two kinase proteins which are AKT and PDK1 heading to the plasma membrane and activating AKT. The AKT activation causes Rheb become active, it then triggers mTOR. ${ }^{9}$ The mTOR will activate $\mathrm{p} 70 \mathrm{~S} 6 \mathrm{~K}$ and phosphorylation of 70 and $85 \mathrm{kDa}$ isoform S6K. ${ }^{13}$ The S6K then phosphorylates transcription factors of in the nucleus, which then inhibits CDK inhibitor. As a result, there is a $C D K$ activation and it stimulates cell proliferation of macrophages. ${ }^{14}$

Terpenoid saponins can increase the number and activity of macrophages, which also Centella asiatica's mechanism of immunomodulatory effect through the $\mathrm{G}$ receptor protein. Centella asiatica has terpenoid saponins as dominan bioactive. This causes the G protein with GDP in the cell membrane become closer to the ligand. The GDP will be replaced by GTP so that the $G$ protein becomes active. Next, the binding between protein G and GTP heads to adenyl cyclase, then it activates adenyl cyclase $C$ phospolipase to be phosphoinositol and results in triphosphat inositol (IP3) and diacylglycerol (DAG). PIP3 will follow the pathway just as the effect of tannins administration, while DAG will produce a protein kinase $C$ activates IKB kinase (IKK). Phosphorylase of IKK inhibits IKB, where IKB will be complex with NF-kB in the cytoplasm. This phosphorylation marks the degradation of I $\mathrm{kB}$ by the proteasome, which then releases NF-kB from complex inhibition. NF-kB protein is then freed and it then is transported into the nucleus, will next activate gen transcription that activates NFkB. ${ }^{11,15,16}$

In previous studies, Astragalus plants containing terpenoid saponins can increase NFkB expression along with mRNA from IL-1B dan TNF- $\mathrm{a}$ ctyokines. Terpenoid saponins causes effects of imunostimulator. ${ }^{17-19}$ In the next process, it will trigger increasing number and activity of macrophages just as the ones occur during EMBS gel administration. This fact indicates that EMBS gel also possesses imunostimulator characteristic, because it is able to increase the number of macrophages in this study.

Macrophages play an important role in wound healing, since they produce growth factors, trigger angiogenesis and fibrogenesis. The released macrophages will fagocyte bacteria and clean up tissue debris. During the transition from the inflammatory process to the repair of wound process, the macrophages will stimulate cell migration, proliferation, and matrix network formation. The growth factors, among others, for angiogenesis include TGFB, VEGF and FGF-2. ${ }^{20-22}$

In a condition lack of macrophages, what happens is the inhibition of wound healing. ${ }^{23}$ It needs a balance number of neutrophils and macrophages in wound healing. On the other hand, in a chronical inflammation condition which inhibits wound healing, there is increasing number of neutrophils which trigger macrophage excess. This situation causes severe wound damage caused by too long hypoxia. ${ }^{8,24}$

Macrophages can control signals in angiogenesis process during the formation of granulation tissue which occur from the $4^{\text {th }}$ until the $10^{\text {th }}$ day after a wound was formed. ${ }^{21,25}$ Neovasculars during the process of formation of granulation tissue are controlled by many cytokines and growth factors. Normally, macrophages during wound healing process are cells which prepare angiogenesis process while stopping $i^{21,25,26}$, This phenomenon also occurs in the administration of Terminalia chebula extract which can accelerate wound healing through synergy effect of metanin 
and other bioactives. The other studies indicate that the synergizing effect occurs when tannins and saponins are simultaneously given..$^{27,28}$

In EMBS gel of $37.5 \%$ concentration, there is a strengthening effect of bioactives of condensed tannins and terpenoid saponins, resulting in increasing number of macrophage and neovascular cells. Mauli banana stem as an immunostimulator can increase the number of macrophage cells. Macrophages play an important role in wound healing which produce growth factors and trigger angiogenesis, so it can be increasing the neovascular cells. The angiogenesis process which is a critical part in the process of wound healing. Mauli banana stem as an antioxidant requires nutrients that support cell metabolism, as well as tannins and saponins to form the granulation tissue consisting of blood vessels that need oxygen for the improvement and growth of blood vessels.

Mauli banana is the antioxidant and immunostimulator agent, so it called an immunomodulator topical drug. This research proved EMBS gel of $37.5 \%$ cencentration can be recommanded as the topical drug to accelerate wound healing including traumatic ulcer. It can be concluded EMBS gel within concentration of $37.5 \%$ can accelerate ulcer healing through the increasing number of macrophage and neovascular cells.

\section{REFERENCES}

1. Cavalcantel GM, de Paulal RJS, de Souzall LP, Sousalll FB, Motalll MRL, AlvesIll APNN. Experimental model of traumatic ulcer in the cheek mucosa of rats. Acta Cirúrgica Brasileira 2011;26(3):299.

2. Laskaris G, Treatment of oral diseases: a concise textbook. New York: Thieme, 2005. P. 169.

3. Regezi, Joseph A, Sciuba JJ, Jourdan RCK. Oral pathology: clinical pathologic correlations. $5^{\text {th }}$ Ed. Saunders, St Louis. 2015. P. 23-6.

4. Field A, Longman L. Tyldesley's Oral Medicine, Ed $5^{\text {th }}$, New York: Oxford, 2003. P. 51.

5. Apriasari ML. The management of chronic traumatic ulcer in oral cavity. Maj Kedok Gigi Dent J 2012;45(2):68-72.

6. Apriasari ML, Iskandar, Suhartono E. Kandungan ekstrak metanol batang pisang mauli (Musa sp) $100 \%$. Internat J Bioscince Biochemistry and Bioinformatics , 2014;4(2):110-5.

7. Apriasari ML, Endariantari A, Oktavianty IK, The effect of $25 \%$ mauli banana stem extract gel to increase the epithel thickness of wound healing process in oral mucosa. Majalah Kedokteran Gigi Dental Journal, 2015;48(3): 150-3.

8. Apriasari ML, Dachlan YP, Ernawati DS. Effect of musa acuminata stem by immunohistochemistry test in ulcer. Asian J Biochemistry 2016;11(3):135-41.

9. Albert B, Johnson A, Lewis J, Raff M, Robert K, Walter P. Moleculer biology of the cell. $5^{\text {th }}$ ed. Garland Science. United States of Amerika. 2008. P. 928-30.

10. Taher M, Majid FAA, Sarmidi MR, A proantocyanidin from cinnamomum zeylanicum stimulates phosphorylation of insulin receptor in 3T3-L1 adipocytes. Jurnal Teknologi 2006;44(F):53-68.

11. Besung INK. Pegagan (Centella asiatica) sebagai alternatif pencegahan penyakit infeksi pada ternak. Buletin Veteriner Udayana 20091(2):61-7.

12. Tsala DE, Amadou D, Habtemariam S. Natural wound healing and bioactive natural products. Phytopharmacology 2013;4(3):532-60.

13. James MJ, Zzomerdijk JCBM, Phosphatidylinositol 3-kinase and mTOR Signaling Pathway Regulate RNA Polymerase I Transcription in Response to IGF-1 and Nutrients. The Journal of Biological Chemistry 2004;279(10):8911-18.

14. Mori S, Nada S, Kimura H, Tajima S, Takahashi Y. The mtor pathway controls cell proliferation by regulating the foxo3a transcription factor via SGK1 Kinase. PLoS ONE. 2014;9(2):e88891.

15. Brancato SK, Albina JE. Mini review: wound macrophages as key regulators of repair origin, phenotype, and function. American J Pathology 2011;178(1):19-25.

16. Napetschnig J, Wu H. Molecular Basis of NF-kB Signaling. Annu Rev Biophys 2013;42(19):1-19.

17. Malek S, Chen Y, Huxford T, Ghosh G. IkBB, but not $I K B a$, functions as a classical cytoplasmic inhibitor of NF-KB dimers by masking both $\mathrm{NFKB}$ nuclear localization sequences in resting cells. J Biol Chem 2001;276(48):45225-35.

18. Huang C, Jacobson K, Scaller MD. A role for jnk-paxillin signaling in cell migration. Cell 
Cycle 2004;3(1):4-5.

19. Papa S, Zazzeroni F, Pham CG, Bubici C, Franzoso G. Linking JNK signaling to NFkB: A key to survival. J Cell Science 2004;117(22):5197205.

20. Morgan MJ, Liu Z. Review: crosstalk of reactive oxygen species and NFkB signaling. Cell Research 2012;21:103-115. Larjava H, Oral Wound Healing; Cell Biology and Clinical Management. Wiley Blackwell, West Sussex, UK. 2011. P. 43

21. Bedir E, Pugh N, Calis I, Pasco DS, Khan IA, Immunostimulatory Effects of CycloartaneType Triterpene Glycosides from Astragalus Species. Biol Pharm Bull, 2000;23(7):834-7.

22. Tonnesen MG, feng $X$, Clarck RAF. Angiogenesis in wound healing. The cosiety for investigative dermatology 2000;5(1):40-5.

23. Guo S, Dipietro LA. Factors affecting wound healing. J Dent Res 2010;89(3):219-29.
24. Soni $H$, Singhai Ak. A recent update of botanical for wound healing activity. Internat Res J Pharam 2012;3(7):1-6.

25. Larjava $\mathrm{H}$. Oral wound healing; cell biology and clinical management. Wiley Blackwell, West Sussex UK. , 2012. P. 43.

26. Brancato SK, Albina JE. Mini review: wound macrophages as key regulators of repair origin, phenotype, and function. Am J Pathology 2011;178(1):19-25.

27. Majewska I, Darmach EG. Proangiogenic activity of plant extracts in accelerating wound healing: A new face of old phytomedicines. Acta Biochimica Polonica 2011;58(4):449-60.

28. Li K, Diao $\mathrm{Y}$, Zhang $\mathrm{H}$, Wang $\mathrm{S}$, Zhang Z, Yu $B$, Huang $S$, Yang $H$. Tannin extract from immature of terminalia chebula fructus retz promote cutaneous wound healing in rats. BMC Complementary and Alternative Medicine 2011;86(11):1-9. 